This item was submitted to Loughborough's Research Repository by the author.

Items in Figshare are protected by copyright, with all rights reserved, unless otherwise indicated.

\title{
Rapid fabrication of efficient P-type perovskite-sensitized solar cells using hot-air drying method
}

PLEASE CITE THE PUBLISHED VERSION

https://doi.org/10.1016/j.matlet.2020.127412

PUBLISHER

Elsevier

VERSION

AM (Accepted Manuscript)

\section{PUBLISHER STATEMENT}

This paper was accepted for publication in the journal Materials Letters and the definitive published version is available at https://doi.org/10.1016/j.matlet.2020.127412

\section{LICENCE}

CC BY-NC-ND 4.0

\section{REPOSITORY RECORD}

Alessa, Hussain, Inzamam Nawas Nawas Mumthas, Mohamad Firdaus Mohamad Noh, Jagdeep Sagu, Upul Wijayantha-Kahagala-Gamage, and Mohd Asri Mat Teridi. 2020. "Rapid Fabrication of Efficient P-type Perovskite-sensitized Solar Cells Using Hot-air Drying Method”. Loughborough University. https://hdl.handle.net/2134/14247443.v1. 
Rapid fabrication of efficient P-type perovskite-sensitized solar cells using hot-air drying method

Hussain Alessaa, $\Uparrow$, Inzamam Nawas Nawas Mumthasb, Mohamad Firdaus Mohamad Nohb, Jagdeep Saguc,K.G.U. Wijayanthac, Mohd Asri Mat Teridib,

介aDepartment of Chemistry, Faculty of Applied Science, Umm Al-Qura University, Makkah, Saudi ArabiabSolar Energy Research Institute, Universiti Kebangsaan Malaysia, 43600 Bangi, Selangor, MalaysiacDepartment of Chemistry, Loughborough University, Loughborough, Leicestershire, LE 11 3TU, UK

\section{Abstract}

The successful development of organic-inorganic perovskite materials mainly based on $\mathrm{CH} 3 \mathrm{NH} 3 \mathrm{~Pb}$ I3hasimproved the PCE of solar cells significantly and reduced the fabrication cost relatively. The majority ofthe researches focused on studying different ways of improving the performance and stability of per-ovskite devices with less attention paid to minimizing the time of fabrication. The reduction of fabrica-tion time can simultaneously reduce the fabrication cost and boost the industrial manufacturingcapability. In this work, we report a simple and rapid method of making $\mathrm{CH} 3 \mathrm{NH} 3 \mathrm{Pbl} 3$ layer at ambientlaboratory conditions and applying it for advancing the photonto-electricity conversion efficiency ofliquid-state CuO-based perovskite-sensitized solar cells. The whole fabrication process starting from elec-trodepositing $\mathrm{CuO}$ to sandwiching counter electrode entails less than $10 \mathrm{~min}$ and the device efficiencyreaches up to $0.35 \%$ under one sun illumination.

\section{Introduction}

Organic-inorganic metal halide perovskite mainly based onCH3NH3Pbl3is an efficient light absorber capable of improvingthe PCE of solar cells and reduced the fabrication cost. Perovskitematerials possess high carrier mobilities, large defect tolerance,tunable band gap, long diffusion length and low exciton bindingenergy[1,2]. However, the standard fabrication procedure, wherethe $\mathrm{CH} 3 \mathrm{NH} 3 \mathrm{Pbl} 3$ phase is usually formed by dissolving perovskitesalts $(\mathrm{CH} 3 \mathrm{NH} 3 \mathrm{I}$ and $\mathrm{PbI}$ ) in a polar solvent before being spin coatedand annealed on a substrate[3,4], is slightly time-consuming andthe process must be conducted in an inert atmosphere. Therefore,methods that utilize shorter fabrication time and capable for ambi-ent air processing must be developed for commercializationpurpose. $\mathrm{CH} 3 \mathrm{NH} 3 \mathrm{~Pb} / 3$ can also be used to replace organic dye as sensi-tizer in liquid-state p-type dye-sensitized solar cells (DSSCs)[5].The development of p-type DSSCs, where the light absorbing mate-rial is sensitized on a photocathode, is very important for realisingthe production of highly efficient tandem solar cells. To date, one of the potential photocathodes for DSSCs is CuO because $\mathrm{CuO}$ is nat-urally abundant, cost-effective, non-toxic and highly conductive.Suzuki et al. were the first group that utilised $\mathrm{CuO}$ as photocathodesensitised with different dyes and obtained $0.3 \mathrm{~mA} \mathrm{~cm} 2,0.115 \mathrm{~V}, 0.011 \%$ for Jsc, Vocand PCE, respectively[6]. Despite this success, the study on CuO-based DSSCs currently is very scarce and therecorded efficiency of the CuO-based devices hardly surpasses0.2\%[7]. Here, we report on the first development of liquidstateCuO-based perovskite-sensitized solar cells (PSCs). We also presenta cheap, rapid hot-air drying method for making $\mathrm{CH} 3 \mathrm{NH} 3 \mathrm{~Pb}$ /3filmswhich enables complete fabrication of liquid-state PSCs in 
lessthan $10 \mathrm{~min}$. This work is an extension from our previous reportrelated to rapid fabrication of CuO by electrodeposition[8].

\section{Experimental}

FTO substrates (Pilkington, TEC 8) are cleaned successivelyusing soapy water, 2-propanol, deionised water, acetone andethanol, in ultrasonic bath for $10 \mathrm{~min}$. The substrates were keptin ethanol prior to fabrication process. CuO was deposited onFTO substrates using a method reported by Sagu et al.[8]. Basi-cally, $\mathrm{CuO}$ was electrodeposited from aqueous solution containing25 mM CuSO4at1.5 V with respect to $\mathrm{Ag} / \mathrm{AgCl} / 3 \mathrm{M} \mathrm{KCl}$ for $120 \mathrm{~s}$, followed by washing with deionised water before annealing at $500^{\circ} \mathrm{C}$ for $60 \mathrm{~s}$. After cooling at room temperature, the FTO/CuOelectrodes were coated with $\mathrm{CH} 3 \mathrm{NH} 3 \mathrm{~Pb} / 3$ using rapid heat gundrying method. 20IL of $1 \mathrm{M} \mathrm{PbI} 2$ in dimethylformamide (DMF)was casted onto CuO/FTO and allowed to fill the pores for1 min. Then the excess Pbl2was removed by tissue before usinga hot-air dryer set at $70^{\circ} \mathrm{C}$. Subsequently, the electrode wasdipped in $\mathrm{CH} 3 \mathrm{NH} 3 \mathrm{I}$ solution (10 mg/mL isopropanol) for $1 \mathrm{~min}$ fol-lowed by drying at $70^{\circ} \mathrm{C}$ for $1 \mathrm{~min}$ using the heat-gun dryer. TheFTO/CuO/CH3NH3Pbl3electrodes were filled with the I/I3elec-trolyte $(500 \mathrm{mM}$ Lil, $250 \mathrm{mM} \mathrm{I2,} 30 \mathrm{mM} \mathrm{CO}(\mathrm{NH2}$ )2and $300 \mathrm{mMtert}$-butylpyridine in anhydrous ethyl acetate) and sandwichedwith Pt as a counter electrode. The whole fabrication process was performed in ambient laboratory atmosphere without humidity controlling system.

\section{Results and discussion}

The X-ray diffraction (XRD) pattern of CuO films deposited onFTO substrates with and without $\mathrm{CH} 3 \mathrm{NH} 3 \mathrm{Pbl} 3$ sensitizer areshown inFig. 1 (a). Characteristic peaks at $35.7^{\circ}, 38.8^{\circ}, 54^{\circ}$ corre-sponding to

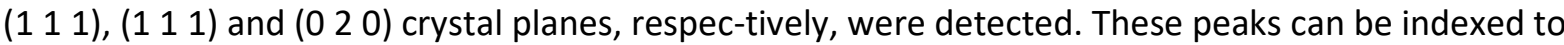
themonoclinic structure of CuO (JCPDS card No. 48-1548)[9]. Withthe help of Scherrer formula and the broadening of ( $\left.\begin{array}{llll}1 & 1 & 1\end{array}\right)$ diffrac-tion peak, the crystallite size was estimated to be $32 \mathrm{~nm}$. Peaksbelonging to perovskite were observed when the $\mathrm{CuO}$ samplewas coated with $\mathrm{CH} 3 \mathrm{NH} 3 \mathrm{Pbl} 3$. However, strong diffraction peakparticularly at $12.7^{\circ}$, which was assigned to the $\left(\begin{array}{l}0 \\ 0\end{array}\right)$ peak ofa photo-inactive cubic $\mathrm{Pbl2}$, is noticeable due to incomplete con-version of $\mathrm{Pbl2}$ to perovskite[10]. This could be attributed to theemployment of ambient air processing approach, the low temper-ature of hot air treatment $\left(70^{\circ} \mathrm{C}\right)$ and short soaking time in $\mathrm{CH} 3-\mathrm{NH} 3 \mathrm{I}$ solution. The existence of Pbl2layer might be useful forsurface passivation because the layer can inhibit recombinationprocess between electrons and holes at the perovskite/photocathode interface [11].

The FTO/CuO/perovskite film showed significant light absorp-tion in the range of visible to near infrared as represented inFig. 1(b). The absorption spectra indicated sharp absorption edgeat 760 $\mathrm{nm}$ which is consistent with the bandgap of perovskite( $1.6 \mathrm{eV})[12]$. From this analysis, it can be expected that the $p$-type solar cells will deliver high efficiency due to improved currentgeneration. One of the prerequisite for achieving high PCE in PSCsis to obtain high surface coverage of perovskite film. As observedfromFig. 1(c), the hot-air treatment employed for fabricating $\mathrm{CH} 3-\mathrm{NH} 3 \mathrm{~Pb}$ blayer homogenously covered the surface of FTO-coatedCuO and only few pinholes were observed. Thus, there should be improvement in the performance of the fabricated devices when using this method.

To analyze the effect of the perovskite sensitization method, iodide/triodide electrolyte was added to the cell system and sandwiched with platinum sheet for creating a liquid-state CuO-basedPSC with configuration $\mathrm{FTO} / \mathrm{CuO} / \mathrm{CH} 3 \mathrm{NH} 3 \mathrm{~Pb} / 3 /(\mathrm{I} / \mathrm{I} 3) / \mathrm{Pt}$. The pho-tovoltaic performance was measured under standard one sun con-ditions as presented inFig. 2(a). The champion solar cell producedVoc,Jsc, FF and PCE of $0.137 \mathrm{~V}, 5.95 \mathrm{~mA} \mathrm{~cm} 2,43 \%$ and $0.35 \%$,respectively. Meanwhile, the corresponding average performanceof several devices prepared under similar condition is 0.129 
$\mathrm{V}, 4.82 \mathrm{~mA} \mathrm{~cm} 2,45 \%$ and $0.27 \%$. Apparently, the present result(CuO-based PSCs) is better than other p-type liquid-state DSSCsbased on $\mathrm{CuO}$ photocathode as reported in previous studies. Forexample, Sumikura et al.[6]and Langmar et al.[7]acquired merely $0.01 \%$ and $0.10 \%$ PCE, respectively, which is majorly due to low JSCvalue ( $<3 \mathrm{~mA} \mathrm{~cm} 2)$. The improved performance of our devicecould be attributed to the remarkable improvement of light absorp-tion when $\mathrm{CH} 3 \mathrm{NH} 3 \mathrm{Pbl} 3$ layer was fabricated using our developedtechnique. To further investigate the source of the photocurrent,an identical cell was made without $\mathrm{CH} 3 \mathrm{NH} 3 \mathrm{Pbl}$ layer and the cellbehaviour under light illumination and dark condition is presentedinFig. 2(b). It is obvious that the Jscand Voc produced in the absence of perovskite layer approached zero confirming that the perovskite layer is the key parameter in improving the PCE parameters of our cell.

Fig 2(c) displays the incident photon-to-electricity conversionefficiency (IPCE) spectrum which was used to determine the exter-nal quantum efficiency (EQE) of the cells. The IPCE spectrumincreased steadily from the UV region to near IR before startingto decrease at around $760 \mathrm{~nm}$, which matched well with the bandgap of perovskite determined from UV-Vis analysis. The wave-length dependent photocurrents were integrated to calculate thephotocurrent of the solar cell. The integrated Jscis $6.58 \mathrm{~mA} . \mathrm{cm} 2$ which is in a good agreement with the value obtained from theJ-V curve. It is worth mentioning that the device lifetime is rathershort $(<10 \mathrm{~min})$ because $\mathrm{CH} 3 \mathrm{NH} 3 \mathrm{~Pb} / 3$ rapidly dissolves in the redoxelectrolyte. Therefore, further device optimization is still underwayfor improving the efficiency and stabilizing the performance. How-ever, the present work suggests that the two-step hot-air drying method developed in this work is practicable for preparing a func-tional perovskite sensitizer and advantageous in terms of rapid fabrication process.

The effect of changing light intensity on liquid-state CuO PSCswas also studied and the corresponding photovoltaic parametersare presented inFig. 3(a)-(e). Linear increase in Jscand Vocwasobserved upon increasing the incident photon concentration. Suchbehaviour could be attributed to the enhanced excitation ofelectron-hole pairs and less charge recombination under intensedlight illumination. Meanwhile, FF value experienced slight dropas the light intensity increased which ultimately affected the over-all device efficiency. Despite the decrease of efficiency, this analy-sis actually implies that our liquid-state CuO-based PSCs are moreeffective for indoor light harvesting or generation of electrical power during cloudy conditions.
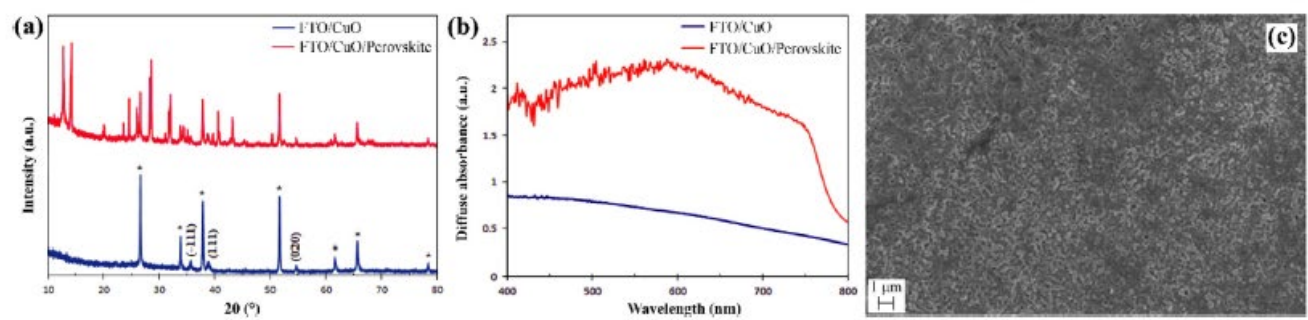

Fig 1. (a) XRD patterns and (b) absorption spectra of $\mathrm{CuO}$ before and after being sensitized with $\mathrm{CH}_{3} \mathrm{NH}_{3} \mathrm{Pbl}{ }_{3}$. (c) FESEM image of perovskite layer grown on FTO-coated CuO by hot-air drying method. 

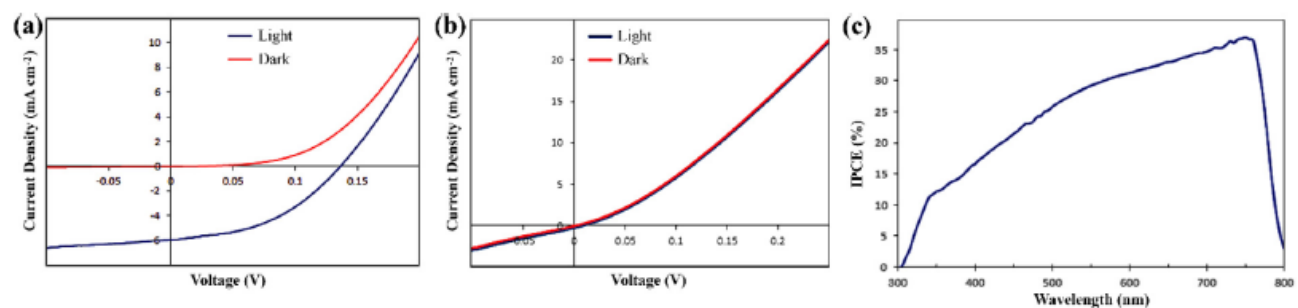

Fig. 2. (a) Photovoltaic performance of a complete cell $\mathrm{FTO} / \mathrm{CuO}_{/} \mathrm{CH}_{3} \mathrm{NH}_{3} \mathrm{~Pb}_{3} /\left(\mathrm{I}^{-} / \mathrm{ll}_{3}^{-}\right) / \mathrm{Pt}$. (b) Photovoltaic performance in the absence of the perovskite layer $\mathrm{FTO} / \mathrm{CuO} /\left(\mathrm{I}^{-} / \mathrm{I}_{3}^{-}\right) /$ Pt. (c) The IPCE of FTO/CuO/CH $\mathrm{NH}_{3} \mathrm{Pbl}_{3} /\left(\mathrm{I}^{-} / \mathrm{l}_{3}\right) / \mathrm{Pt}$.
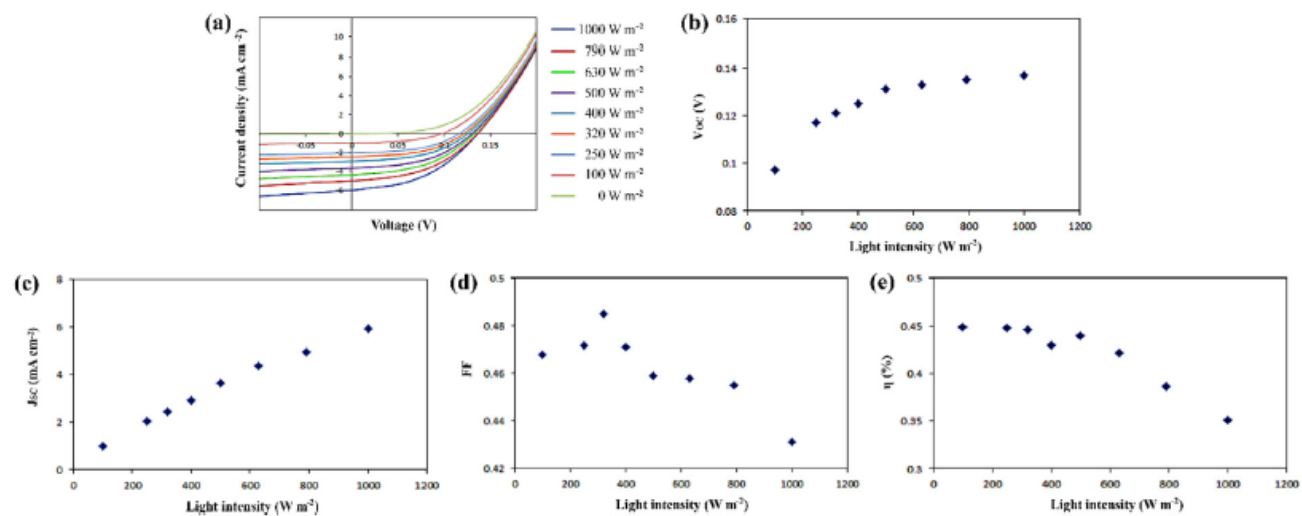

Fig 3. (a) J-V curves and the corresponding (b) $V_{O c}$ (c) Jsc. (d) FF and (d) PCE of the liquid-state electrodeposited CuO-based PSCs under different light intensity.

\section{Conclusion}

We have developed a facile and rapid method for making $\mathrm{CH} 3-\mathrm{NH} 3 \mathrm{~Pb} 33$ layer through hot-air dyring process and successfullyapplied it for sensitising $\mathrm{CuO}$ electrodes. This process consumedless than 10 min for complete assembly of the liquid-state CuO-based PSCs. The cell efficiency achieved $0.35 \%$ which could bedue to the effective light absorption by perovskite material andthe compatibility between $\mathrm{CuO}$ and perovskite as photocathodeand sensitizer, respectively. We believe that this work will helpadvancing the solar cell technology towards the development of liquid-state tandem solar cells with reduced fabrication time and cost.

\section{Acknowledgements}

Hussain Alessa would like to thank Umm Al-Qura University forthe financial supports. Mohd Asri Mat Teridi would like to thankUniversiti Kebangsaan Malaysia for the financial supports throughgrant Dana Impak Perdana (DIP-2018-009).

\section{References}

[1]C.H. Teh, R. Daik, E.L. Lim, C.C. Yap, M.A. Ibrahim, N.A. Ludin, K. Sopian, M.A.Mat Teridi, J. Mater. Chem. A 4 (2016) 15788-15822.

[2]T. Zhou, M. Wang, Z. Zang, L. Fang, Adv. Energy Mater. 9 (2019) 1900664.

[3]M.F. Mohamad Noh, N.A. Arzaee, J. Safaei, N.A. Mohamed, H.P. Kim, A.R. MohdYusoff, J. Jang, M.A. Mat Teridi, J. Alloys Compd. 773 (2019) 997-1008.

[4]M. Wang, H. Wang, W. Li, X. Hu, K. Sun, Z. Zang, J. Mater. Chem. A 7 (2019)26421-26428.

[5]H. Wang, X. Zeng, Z. Huang, W. Zhang, X. Qiao, B. Hu, X. Zou, M. Wang, Y.-B.Cheng, W. Chen, A.C.S. Appl, Mater. Interfaces 6 (2014) 12609-12617. 
[6]S. Sumikura, S. Mori, S. Shimizu, H. Usami, E. Suzuki, J. Photochem. Photobiol. AChem. 194 (2008) 143-147.

[7]O. Langmar, C.R. Ganivet, A. Lennert, R.D. Costa, G. de la Torre, T. Torres, D.M.Guldi, Angew. Chemie Int. Ed. 54 (2015) 7688-7692.

[8]J.S. Sagu, T.A.N. Peiris, K.G.U. Wijayantha, Electrochem. Commun. 42 (2014)68-71.

[9]A. Savva, I.T. Papadas, D. Tsikritzis, G.S. Armatas, S. Kennou, S.A. Choulis, J.Mater. Chem. A 5 (2017) 20381-20389.

[10]D. Gedamu, I.M. Asuo, D. Benetti, M. Basti, I. Ka, S.G. Cloutier, F. Rosei, R.Nechache, Sci. Rep. 8 (2018) 1-11.

[11]S. Wang, W. Dong, X. Fang, Q. Zhang, S. Zhou, Z. Deng, R. Tao, J. Shao, R. Xia, C.Song, L. Hu, J. Zhu, Nanoscale 8 (2016) 6600-6608.

[12]H.-S. Ko, J.-W. Lee, N.-G. Park, J. Mater. Chem. A 3 (2015) 8808-8815. 